\title{
Extraction of fat/oil from fleshing by-product using a wet rendering process and combination with organic solvents
}

\author{
Sugihartono*, Dona Rahmawati, Efa Radnawati, Ageng Priatni \\ Center for Leather, Rubber and Plastics, J1. Sokonandi No. 9, Yogyakarta 55166, Indonesia \\ ${ }^{*}$ Corresponding author. Tel. +62 274 512929-563939; Fax. +62 274563655 \\ Email : hsugihartono@ymail.com
}

Submitted: 23 January 2019

Revised: 24 May 2019

Accepted: 27 May 2019

\begin{abstract}
The extraction of fat/oil from fleshing by-products using moist heating (boiled and steamed) produces a fat that contains large amounts of impurities and which is bluish color, whereas when using fatty solvents, it is necessary to dry the ingredients. The purpose of this study was to determine the fat/oil characteristics from fleshing by-products extracted using a combination of wet rendering (temperatures of 80,90 and $100{ }^{\circ} \mathrm{C}$, and times 1,2 and 3 hours) with n-hexane. The combined treatment of wet rendering (temperature $90{ }^{\circ} \mathrm{C}$ and duration 2 hours) with n-hexane gave rise to the production of fat with the highest yield $(11.10 \% \mathrm{w} / \mathrm{w})$. The higher the temperature and the longer the wet rendering process, results in fat with higher levels of free fatty acid and the saponification value, but the lower the number of peroxides and the darker the color. The fats/oils consist of 37 fatty acid compounds, composed of saturated and unsaturated fatty acids. There are six very present fatty acid compounds, namely butyric acid methyl ester, tetradecanoic acid methyl ester, cis-10-pentadecanoic acid methyl ester, palmitoleic acid methyl ester, octadecanoic acid methyl ester and trans-9-elaidic acid methyl ester.
\end{abstract}

Keywords: fleshing by product, extraction, wet rendering, n-hexane, fat/oil.

\section{INTRODUCTION}

Fleshing is one of the processes in leather tanning which aims to remove the remaining meat and fat that is still attached to the skin/hide, so it doesn't interfere with the next process (Prayitno, 2017). Fleshing by-products in the most amount of meat and fat tissue when compared with other by-products. Kanagaraj et al. (2006) reported that one ton of raw skin processing would be reduced by $850 \mathrm{~kg}$ by-products, which consisted of pre-tanning and after tanning by-products. Pre-tanning by-products of $63-73 \%$, consisting of $2-5 \%$ hair, fleshing $56-60 \%$, and $5-7 \%$ trimming), while after tanning as much as $35-40 \%$ includes chrome shaving, chrome split, and buffing dust.

The fleshing by-products contain water, fat, minerals, and protein which are quite high and material process of hair removing and liming (Priebe \& Gutterres, 2012). Material components of fleshing by-products are excellent nutrients for the growth and proliferation of destructive microorganisms. The decomposition of fleshing by-products by microorganisms create a stench that is very stinging and disturbs the comfort of people living around the industry. Therefore, it needs to be dealt with immediately.

A large number of by-products from the leather tanning industry are reusable materials. These by-products can be useful as raw material for other industries. The byproducts of fleshing can be used as industrial raw materials such as gelatin and tallow/fat. (IUE-2. 2008). Extraction of fat/oil from a material can be done in various ways, namely by using an enzyme, mechanical expression (mechanical pressing), rendering (dry rendering and wet rendering), and solvent extraction (fat/oil solvent). The solvents commonly used for extracting fats/oils include: acetone, alcohol (ethanol, isopropanol, methanol, and n-butanol), ether (diethyl ether, dioxane, isopropyl ether), halocarbons (dichloromethane, chloroform), hydrocarbons (benzene, hexane, isooctane, cyclohexane), or the mixture (Susanti et al., 2014). Whereas Susanti et al. (2014) stated that the oil solvents commonly used are acetone, ethanol, ethyl acetate, isopropanol, n-hexane. The selection of solvents is a determining factor for the success of fat/oil extraction. Factors that are taken into account in selecting solvents are selectivity, solvent boiling point, inert, polarity, solubility in water, non-flammable and inexpensive (Sahriawati \& Daud, 2016).

Sutyasmi and Sunaryo (2006) performed fat extraction from fleshing by-products using heating methods (boiled and steamed) and with solvents (alcohol, $\mathrm{CCl}_{4}$, and hexane). The results showed that the fat produced was of low quality (bluish color). High quality fat should be white, yellow or brown depending on the color and content of free fatty acids (Supangat, 1976). Heating fat extraction causes the protein to dissolve and mix with fat makes the low quality of fat. Fat extraction with n-hexane solvents produced a higher yield (Sutyasmi \& Sunaryo, 2006). N-hexane is an organic solvent that is inert, very non-polar, has a low boiling point, can dissolve quickly and perfectly and is more reactive as a solvent so 
that more extracted oil (Aziz \& Fresca, 2009). N-hexane is stable, volatile, and selective in dissolving substances (Handayani \& Juniarti, 2012). Fat/oil extracted from the by-products of fleshing through boiling contains a lot of impurities, while extraction using solvents on the fleshing by-products requires a preliminary treatment, namely drying. Impurities that are included in the fat/oil produced through the boiling process can be separated using fat/ oil solvents without drying. The water content of fat/oil is quite low and others than oil have been separated, so the amount of solvent used in this method is less when compared to the extraction of fat/oil directly from the fleshing by-product. The purpose of this study was to determine the characteristics of fat/oil from fleshing byproducts through a combination of extraction processes with boiling and solvent use.

\section{MATERIALS AND METHODS Materials}

The materials used in this study were by-product of fleshing, water, $\mathrm{n}$-hexane, ammonium sulfate $\left(\left(\mathrm{NH}_{4}\right)_{2} \mathrm{SO}_{4}\right)$. This experiment used by-product of fleshing from one of the leather tanning industries located in Sitimulyo, Yogyakarta, while chemicals were obtained from chemical sales agents in Yogyakarta.

\section{Research Equipment}

Research equipment includes drum reactors, scales, digital scales, filter cloth, glass utensils, electric stoves, gas stoves, waterbath, stainless knives, plastic buckets, stirrers, distillation equipment, GCMS, and a number of other equipment to test fat/oil quality.

\section{Research Method \\ Material preparation}

Skin/hide fleshing in the tanning industry was carried out after the liming process, then by-products of fleshing contain considerable amounts of lime. To obtain free lime - fleshing fat/oil, the lime within the fleshing by-products needs to be removed before the extraction process was carried out. The lime removal (deliming) used ammonium sulfate $\left(\left(\mathrm{NH}_{4}\right)_{2} \mathrm{SO}_{4}\right)$ as much as $2 \%(\mathrm{w} / \mathrm{w})$ and water as much as $200 \%(\mathrm{w} / \mathrm{w})$. Deliming was carried out on a rotating drum for one hour.

\section{Fat/oil extraction}

Fat/oil extraction from by-products of fleshing used the wet rendering process carried out at various temperatures and times $\left(80,90 \& 100{ }^{\circ} \mathrm{C}\right)$ and time $(1$; $2 ; 3$ hours). The by-products of fleshing which have been separated from lime, drained and cut into small pieces $( \pm$ $1.5 \times 1.5 \mathrm{~cm}$ ). Taken as much as $300 \mathrm{~g}$ of cut fleshing waste, then put in a cup of glass and added $600 \mathrm{~mL}$ of water. Then, the heated used a water bath, at temperature and time according to experimental variations. Regular stirring was carried out during heating. Left for 24 hours, then the floating fat/oil was separated and stored in a cup of glass. Use a separating funnel to separate water/ fat based oil, by first heating the fat / oil in the cup until it melts. The next step was the separation of impurities contained in fat/oil used organic solvents namely technical $\mathrm{n}$-hexane ( 1 fat : 5 solvents $\mathrm{w} / \mathrm{v}$ ). The insoluble part of the n-hexane solvent was separated by filtration. Fat/oil was separated from n-hexane by distillation. Furthermore, the oil obtained was placed in a container made of plastic, then testing the physical chemical properties and its constituent components.

Testing the physico-chemical properties of fat/ oil from by-product of fleshing included yield, moisture content, ash content, free fatty acid (FFA), iodine number, saponification rate, peroxide number, fat/oil and color constituent components. Testing was also on by-product of fleshing, namely water content, ash content, protein, fat, and carbohydrates. Testing was carried out using the AOAC procedure (AOAC, 2005). Testing of fatty acid constituents in fat/oil from by-product of fleshing was only carried out at the optimum temperature and extraction time in producing fat/oil.

\section{RESULTS AND DISCUSSION By-product of Fleshing}

The by-product of fleshing that have been through the deliming process were tested and the following results were obtained; water $71.27 \%$, ash $2.21 \%$, protein $10.57 \%$, fat $15.27 \%$ and carbohydrates $0.66 \%$. Water content was high because the material after deliming was only drained and not dried, therefore the by-product of fleshing tested has a high water content. This is in accordance with the statement of Prayitno (2017) that the components of fresh raw skin contain $60-70 \%$ water. The by-product of fleshing consists of the remaining meat and fat tissue which was still attached to the skin. This situation makes the fat content relatively higher than the protein content. The ash content of fleshing by-products is quite high, this condition suggests that in the fleshing by-products contain lots of minerals from process material and which naturally occur in the base material.

\section{Characterization of Fat/oil from Fleshing By-products Yield}

The yield of fat/oil from fleshing by-products was lower than the base material. This situation means that there was still fat/oil left in the processed material. Reducing the size of the material can increase the yield of fat/oil. The small size of the material will facilitate the release of oil from the material, so that the yield becomes higher. The complete fat/oil yield test results are presented in Figure 1.

The yield of fat/oil from fleshing by-products ranges from $7.70-11.10 \%$. This result was still higher than Sutyasmi and Sunaryo (2006) was $4.2-8.5 \%(\mathrm{w} / \mathrm{w})$ by boiling and steaming for $15-60$ minutes. Figure 1 show an increase in yield at 1 and 2 hours extraction time. This is because the longer the extraction time, the more fat that comes out of the tissue so more fat/oil was obtained. However, a decrease in yield occurred at 3 hours extraction 
time. The decrease is thought to occur because the length of extraction time causes fat/oil to be contaminated by air causing fat/oil oxidized and cause damage to the fat/oil and decrease in yield. According to Ketaren (1986), the possibility of damage or rancidity in fat can be caused by 4 factors, namely: 1). Odor absorption by fat. 2). Action by enzymes in tissue containing fat. 3). Microbial action and 4). Oxidation by air oxygen or a combination of two or more of the causes of damage mentioned above. Oxidation by air oxygen (autoxidation) occurs spontaneously if the fat-containing material is left in contact with air.

The increase in fat/oil yield occurs along with the temperature rise as shown in Figure 1. The increase in yield occurs at temperatures of $80^{\circ} \mathrm{C}$ to $100^{\circ} \mathrm{C}$. This situation is caused by the higher the temperature, the lower the viscosity of fat/oil so that the fat/oil is easily removed from the tissue. This is in accordance with what was done by (Sahriawati \& Daud 2016), where the extraction temperature has a significant effect on the yield of milkfish oil. The increase in temperature causes the reaction rate to increase so that the oil/fat that comes out also increases. According to Vogel (1984), several factors that influence the extraction process, namely differences in methods, solvents, temperatures, and extraction times will affect the amount of yield and the quality of extracts obtained. Based on the consideration of energy use, the most beneficial extraction is the treatment using a temperature of $90{ }^{\circ} \mathrm{C}$ for 2 hours.

The extraction time for 2 hours will be obtained fat/oil with the highest yield compared to the extraction time of 1 hour and 3 hours. Fat/oil yield using 2 hours is slightly higher than 3 hours, this means that the extraction time of 2 hours is the most optimum time.

\section{Water Content}

The water content of fat or oil results by extraction are range from $0.47-0.88 \%$, and are presented in Figure 2.
Extraction at $80^{\circ} \mathrm{C}$ and $90^{\circ} \mathrm{C}$ for 1 hour produces the lowest water content, which is $0.47 \%$ and extraction at 100 ${ }^{\circ} \mathrm{C}$ for 3 hours produces the highest water content, which is $0.88 \%$. The extraction time treatment also produces fat or oil with fluctuating water content. Fluctuating was caused when ending heating for $n$-hexane distillation based solely on bubbles formed. Heating was stopped when there was no bubble, so that the water contained in fat or oil still fluctuates between treatments. However, the water content of fat or oil results by extraction by combination of wet rendering with solvent (n-hexane) is very low, which is below $1 \%$. The low water content will make fat or oil become more durable. It was caused, the water can hydrolyze fat or oil and damage it (Derlean, 2009).

\section{Ash Content}

Ash is an inorganic substance which is a residue from the combustion of organic material. The ash content of fat or oil results by extraction are range from 0.08 $0.41 \%$ and are presented in Figure 3. They are lower than ash content of fleshing waste. This condition was caused by the minerals that were included in the wet rendering process which are separated together with impurities in the process of transferring substances using n-hexane.

Extraction at $80{ }^{\circ} \mathrm{C}$ for 3 hours produces the lowest ash content, which is $0.08 \%$ and the highest ash content is produced by extraction at $90{ }^{\circ} \mathrm{C}$ for 3 hours, which is $0.41 \%$. Extraction at $90{ }^{\circ} \mathrm{C}$ for 1 hour and 2 hours produces ash content that relatively low and equal, which is $0.10 \%$.

\section{Free Fatty Acid (FFA) Content}

The FFA content of fat or oil results by extraction are range from $0.36-21.99 \%$ and are presented in Figure 4. They show differences between treatments. Extraction at $80{ }^{\circ} \mathrm{C}$ produces relatively low FFA content and extraction at $100^{\circ} \mathrm{C}$ produces relatively high FFA content.

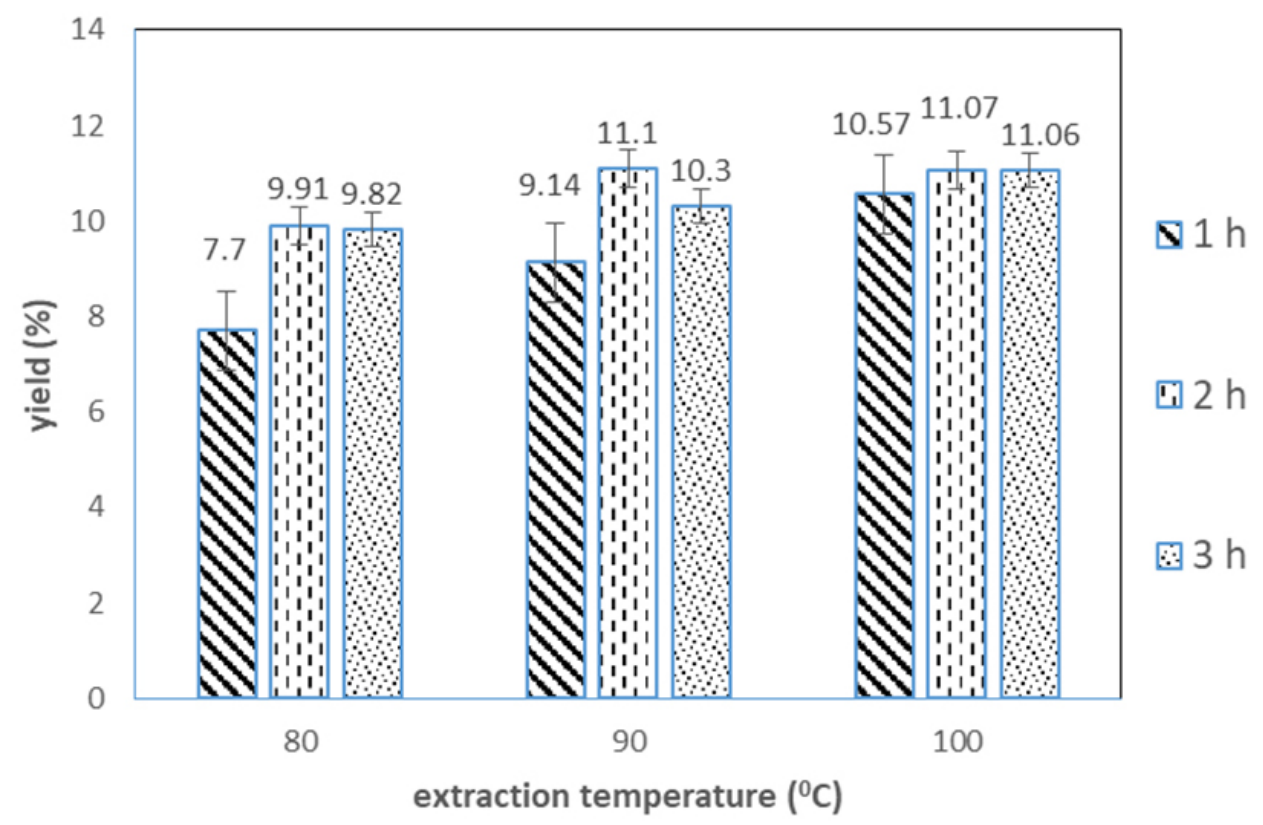

Figure 1. The effect of temperature and time of extraction to yield. 
While, extraction for 1 hour also produces relatively low FFA content. The highest FFA content is produced by extraction at $100{ }^{\circ} \mathrm{C}$ for 3 hours extraction, which is $21.99 \%$. It shows that increasing temperature and time of extraction by combination of wet rendering with solvent (n-hexane) caused increase of FFA content.

Free fatty acids (FFA) are saturated fatty acids resulting from hydrolysis and fat or oil oxidation reactions and contain cholesterol (Sopianti et al., 2017). The hydrolysis and oxidation reactions are the main causes of oil damage. Fat hydrolysis occurs because of the reaction between fat and water dissolved in fat under appropriate conditions of temperature and pressure, besides that it is also triggered in the presence of catalysts such as acids, bases and enzymes (lipase). However, the cause of damage to fat or oil is largely the result of oxidation reactions when compared to hydrolysis reactions (Rukmini \& Raharjo 2010; Karouw \& Indrawanto 2015). According to Derlean (2009) the oxidation speed of fats/oils is influenced, among others, by high temperatures, humidity and sunlight.

\section{Iodine Number}

The iodine number can be used to determine the degree of saturation of fat or oil. The lower the iodine number of fat/oil means that its double bond or degree of unsaturation is lower, and the quality of fat/oil is lower too. But, the higher the degree of saturation of fat/oil means the oil dries faster. The iodine number of fat/oil results by extraction are range from $63.75-84.82$, and are presented in Figure 5.

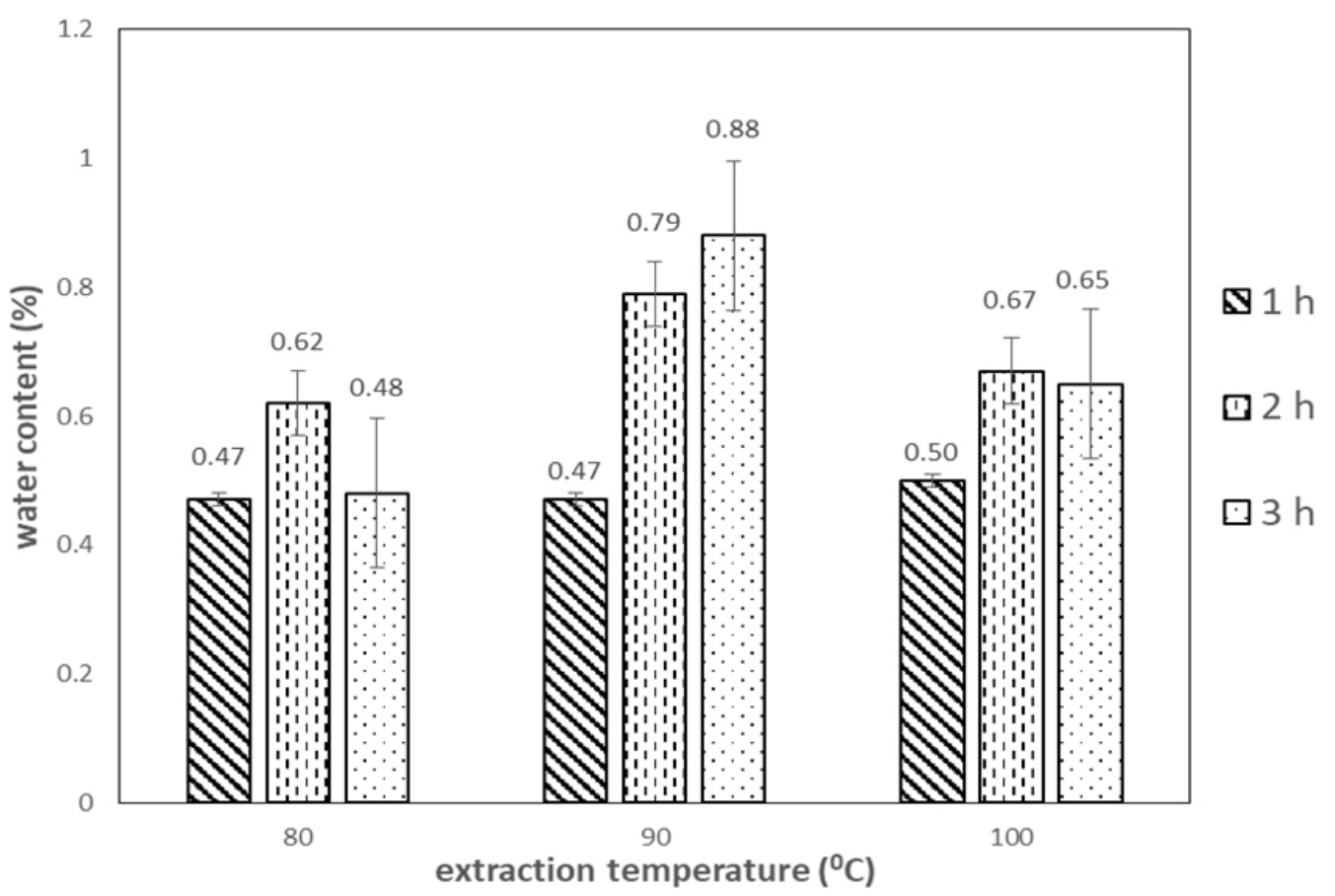

Figure 2. The effect of temperature and time of extraction to water content.

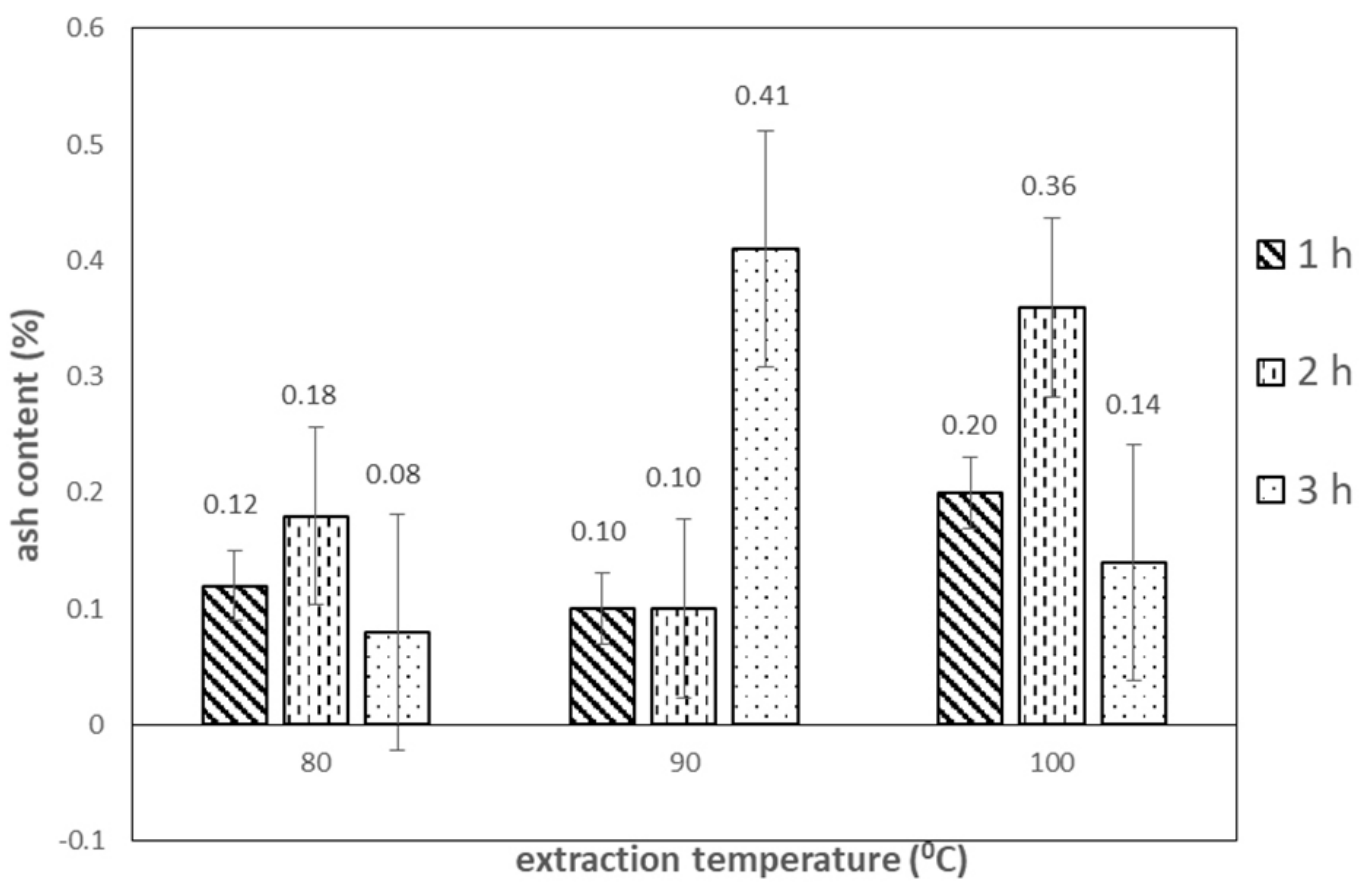

Figure 3. The effect of temperature and time of extraction to ash content. 
The iodine number of temperature and time treatment are fluctuate. Extraction at $80{ }^{\circ} \mathrm{C}$ for 2 hours produces the highest iodine number, which is $84.82 \%$ and extraction at $90{ }^{\circ} \mathrm{C}$ for 3 hours produces the lowest iodine number, which is $63.75 \%$. Figure 5 shows that the iodine number at $80{ }^{\circ} \mathrm{C}$ is high, then decrease at $90{ }^{\circ} \mathrm{C}$, and increases again at $100{ }^{\circ} \mathrm{C}$ extraction temperature. Thus, the iodine number of fat/oil results by extraction from fleshing waste in this study is higher than that reported by (Cuq et al., 1998) and (Priebe \& Gutterres 2012). There were differences iodine numbers that caused by differences in extracted materials and extraction methods. The material was used in the research is fleshing waste of sheep skin, goats and or cows.

\section{Saponification Number}

The saponification number indicates the number of milligrams of $\mathrm{KOH}$ used to soap one gram of fat/oil. The value of saponification number depends on the molecular weight contained in fat/oil. Low molecular weight fats/ oils, consisting of short chain fatty acids (C) and have large saponification number. On the other hand, the high molecular weight fats/oils have small saponification number (Panagan et al., 2011). If a number of fat/oil samples are soaped with excess $\mathrm{KOH}$ solution in alcohol, then $\mathrm{KOH}$ will react with triglycerides (Ketaren, 1986).

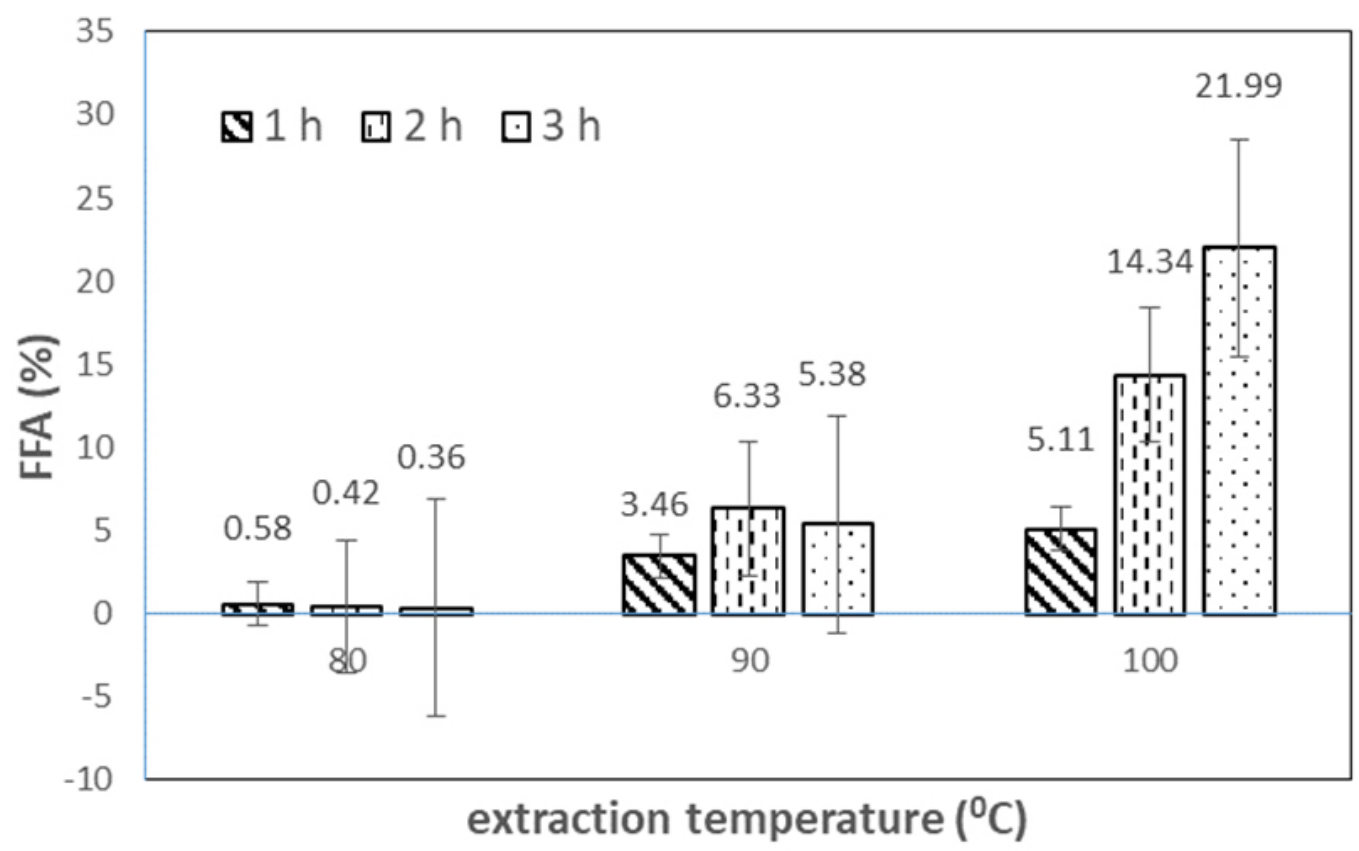

Figure 4. The effect of temperature and time of extraction to free fatty acid content.

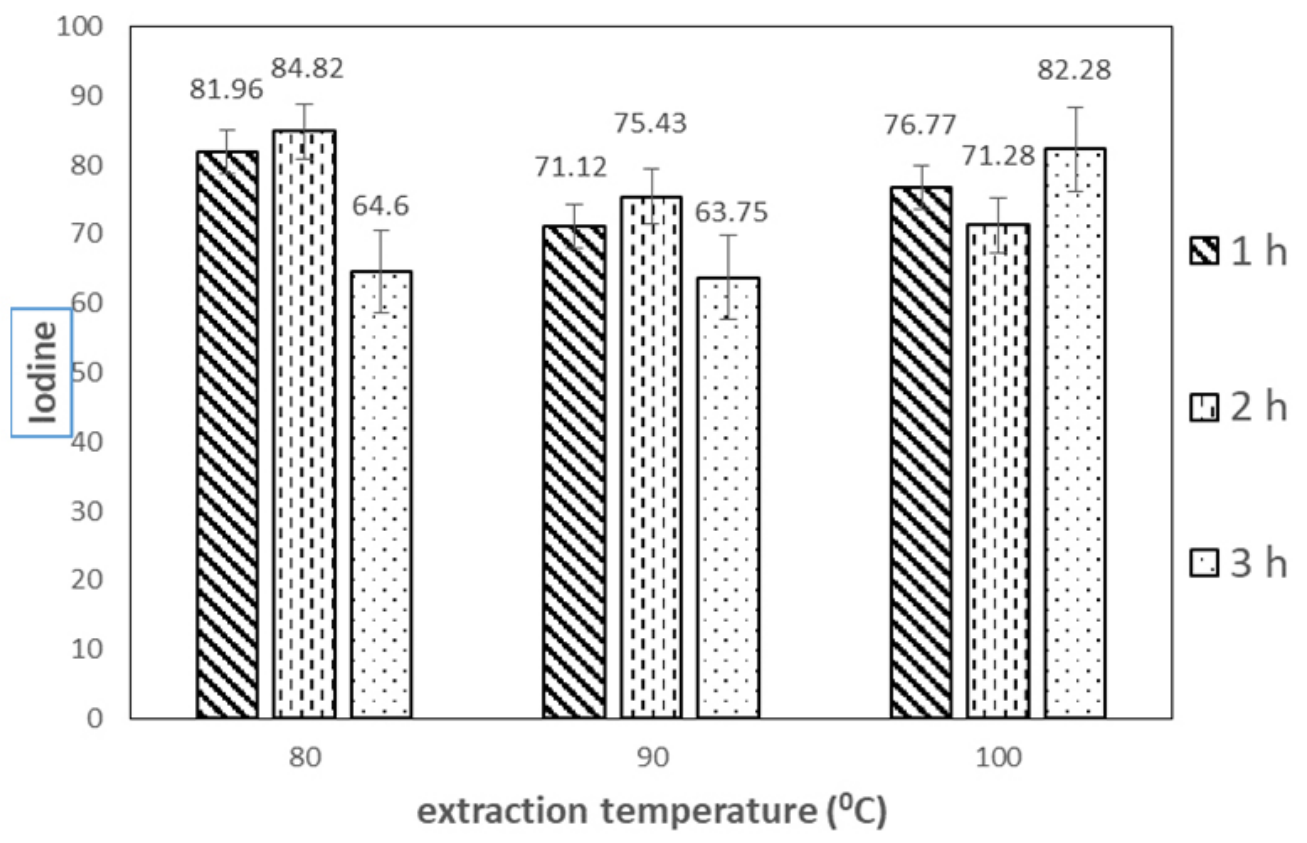

Figure 5. The effect of temperature and time of extraction to iodine number. 
The saponification number of fat/oil results by extraction are range from 5.21 - 77.51 as shown in Figure 6. This value is much smaller than the saponification number for fat of beef, which is 235.57. This is due to the fat of fleshing by-product obtained from sheep skin, goat, and or cow. The saponification number of 5.21 77.51 shows that fat/oil results by extraction has a large molecular weight due to small saponification numbers.

The treatment at a temperature of $80^{\circ} \mathrm{C}$ produced the lowest saponification number, then increased at a temperature of $90^{\circ} \mathrm{C}$, then the highest at a temperature of $100{ }^{\circ} \mathrm{C}$. Likewise in the treatment of the time the pattern follows the temperature, the longer the extraction time the saponification number tends to increase, except for the treatment at a temperature of $90{ }^{\circ} \mathrm{C}$ and for 3 hours. At high temperatures and long periods of oxidation of fats to produce free fatty acids, this condition is thought to be the cause of the high rate of saponification from the treatment temperature of $100{ }^{\circ} \mathrm{C}$ and time of 3 hours (77.51). According to Ketaren (1986), the factors that can accelerate oxidation reactions include light, heat, fat peroxide or hydroperoxide, heavy metals, and lipoxidase enzymes.

\section{Peroxide Number}

Peroxide numbers are used to assess the degree of damage to oil. Unsaturated fatty acids can bind oxygen to their double bonds to form peroxide. The smaller the peroxide number means the better the oil quality. Fat/oil peroxide figures from fleshing side products range from $2.74-5.48 \mathrm{ml} . \mathrm{eq} / \mathrm{kg}$. The complete peroxide number test results are presented in Figure 7.

Peroxide numbers fluctuate, overall the higher the peroxide number extraction temperature tends to decrease. The extraction treatment at $90{ }^{\circ} \mathrm{C}$ and 3 hours produced fat/oil with the lowest peroxide number of $2.74 \mathrm{ml} . \mathrm{eq} / \mathrm{kg}$, and the highest was obtained in the extraction treatment at $80{ }^{\circ} \mathrm{C}$ and 1 hour for $54.48 \mathrm{ml} . \mathrm{eq} / \mathrm{kg}$. Decreasing the number of peroxides at higher extraction temperatures is due to the decomposition of hydroperoxide during the heating process into secondary oxidation products that are unstable (Karouw \& Indrawanto, 2015). If the decomposition rate of hydroperoxide is higher than the rate of formation of hydroperoxide in fat/oil, as a result the peroxide number becomes lower (Rukmini \& Raharjo, 2010). An indication that fat/oil has been oxidized is a high number of peroxides, but it does not always mean lower peroxide numbers indicate the condition of the onset of oxidation (Siswanto \& Mulasari, 2015)

\section{Color}

Fat/oil color from fleshing waste extraction at a temperature $80{ }^{\circ} \mathrm{C}$ is yellow, then extraction at a temperature $90{ }^{\circ} \mathrm{C}$ is light brown and extraction at a temperature at $100{ }^{\circ} \mathrm{C}$ is dark brown. The complete color test results of fat/oil are presented in Figure 8.

Picture from left to right, leftmost oil color is extraction at a temperature $80{ }^{\circ} \mathrm{C}$ for 1 hour, then extraction at a temperature $80^{\circ} \mathrm{C}$ for 2 hours, extraction at a temperature $80^{\circ} \mathrm{C}$ for 3 hours, extraction at a temperature $90{ }^{\circ} \mathrm{C}$ for 1 hour, extraction at a temperature $90{ }^{\circ} \mathrm{C}$ for 2 hours, extraction at a temperature of $90{ }^{\circ} \mathrm{C}$ for 3 hours, extraction at a temperature of $100^{\circ} \mathrm{C}$ for 1 hour, extraction at a temperature of $100{ }^{\circ} \mathrm{C}$ for 2 hours, and extraction at a temperature of $100{ }^{\circ} \mathrm{C}$ for 3 hours. It appears that the higher the temperature and time of extraction, the more

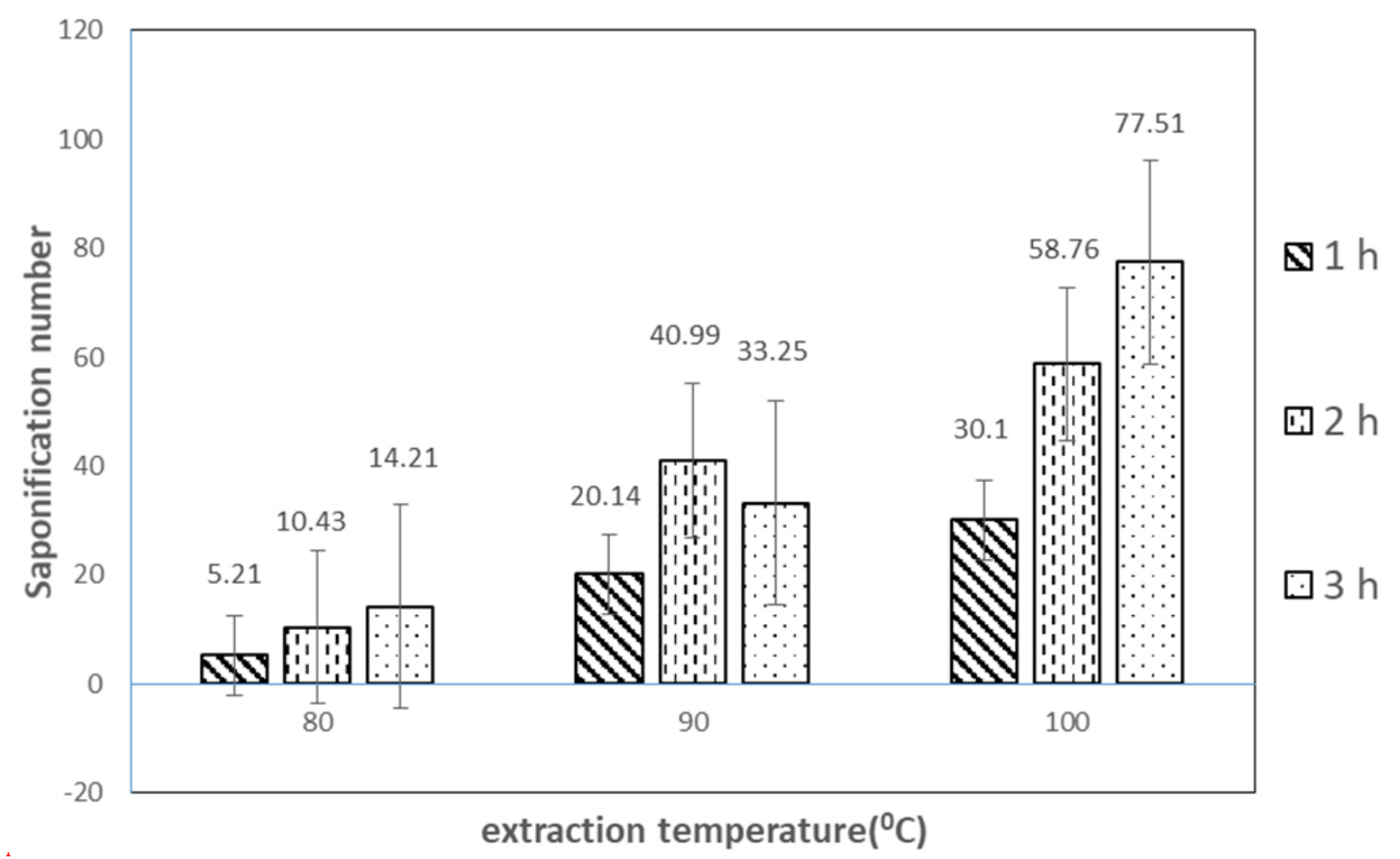

Figure 6. The effect of temperature and time of extraction to saponification number. 
dark the oil will produce.

The fat/oil produced by the extraction at a temperature of $100{ }^{\circ} \mathrm{C}$ is less favorable for further use, because the color is too dark. The color of fat/oil extracted is similar to that reported by Cuq et al. (1998) namely yellow-orange (orange-yellow). The color of fat/oil extracted by fleshing by boiling, steaming and steam for 15 - 60 minutes is bluish (Sutyasmi \& Sunaryo, 2006), then it is said that good colors are white, yellow or brown. The color of oil from the treatment extraction temperature of $90{ }^{\circ} \mathrm{C}$ for $1-3$ hours is relatively good, namely light brown.

The higher the extraction temperature on the fleshing waste, will produced the darker colored oil/fat. The formation of dark colors is caused by a non-enzymatic browning reaction or a Maillard reaction. Maillard reaction is a reaction between carbohydrates, especially reducing sugars with amine groups free of amino acids or proteins that produce brown color and accelerated in the presence of heat.

\section{Components of Fat/oil Composing from Fleshing By- products}

The fatty acid constituent components of fleshing by-products were detected in 37 components, six of which were quite large or dominant (Table 1), consisting of saturated and unsaturated fatty acids. This is as stated by (White et al., 1964) that the fatty acid constituent components of animal fats/oils consist of saturated fatty acids and unsaturated fatty acids.

The fatty acid component which is very small $(<$ $0.2 \%$ ) in fleshing fat/oil as much as 25 , namely: methyl hexanoate, methyl octanoate, methyl decanoate, methyl undecanoate, methyl lauratemethyl tridecanoate, methyl pentadecanoate, methyl palmitate, lenolelaidic acid methyl esters, methyl aracehidate, gamma-lenolenic acid methyl ester, methyl lenolenate, methyl heneicosanoate, cis-1114-eicosadienoic acid methyl ester, methyl docosanoate, Cis-8-11-14-eicosatrienoic acid methyl ester, methyl ester erucate, cis -11-14-17-eicosatrienoic acid methyl, methyl tricosanoate, methyl cis-5-8-11-14-eicosatetraenoic, cis13-16-docosadienoic acid methyl ester, methyl lignocerate, methyl cis-5-8-11- 14-17-eicosapentaenoate, and methyl nervonate, Cis-4-7-10-13-16-19-docosahexaenoate. There are 6 ( six) components of fatty acids whose existence is $\pm 1-2 \%$, namely; myristoleit acid methyl ester, methyl heptadecanoate, cis-10-heptadecenoid acid methyl ester, cis-9-oleic methyl ester, methyl lenoleate, and methyl cis-11-eicocenoate. While the fatty acids whose presence is quite large or dominant in fat / oil from fleshing byproducts are 6 pieces, namely; butyric acid methyl ester, tetradecanoic acid methyl ester, cis-10-pentadecenoid acid methyl ester, palmitoleic acid methyl ester, octadecanoic methyl ester, and trans-9-elaidic acid methyl ester. The test results of the main fatty acid components or the dominant ones from the best treatment are the temperature of $90{ }^{\circ} \mathrm{C}$

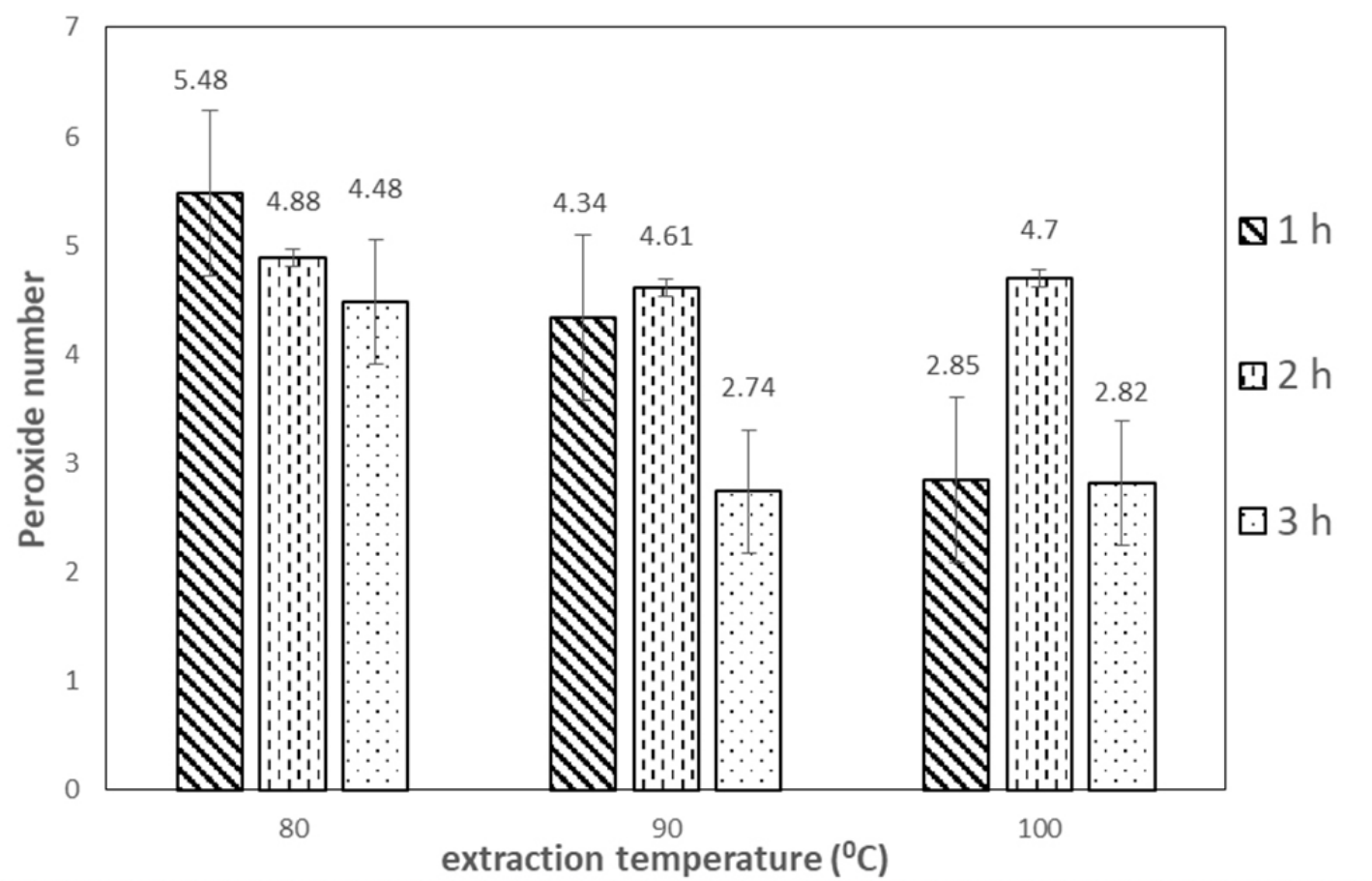

Figure 7. The effect of temperature and time of extraction to Peroxide number.

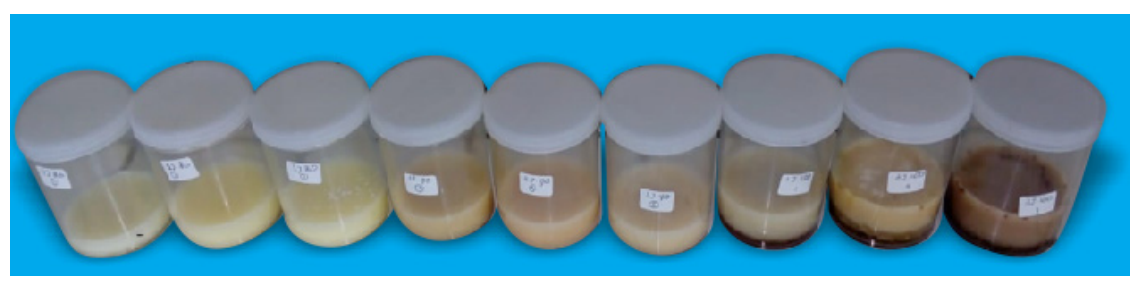

Figure 8. The effect of temperature and time of extraction to color. 
Table 1. The main constituent component of fat.

\begin{tabular}{clc}
\hline No. & \multicolumn{1}{c}{ Name of fatty acids } & Fat at T2W2 treatment (\%) \\
\hline 1. & Butyric acid methyl ester & 23.84 \\
2. & Tetradecanoic acid methyl ester & 2.87 \\
3. & Cis-10-pentadecenoid acid methyl ester & 17.18 \\
4. & Palmitoleic acid methyl ester & 2.97 \\
5. & Octadecanoic acid methyl ester & 9.48 \\
6. & Trans-9-elaidic acid methyl ester & 34.52 \\
\hline
\end{tabular}

Information: $\mathrm{T}_{2}=90^{\circ} \mathrm{C}$ and $\mathrm{W}_{2}=2$ hours.

and the complete time of 2 hours are presented in Table 1.

White et al. (1964) stated that the dominant component of saturated fatty acids in animal fats/oils was palmitic and stearic acid, while non-saturated ones consisted of oleic, palmitoleic and linoleic. Priebe and Gutterres (2012) stated that the fatty acid composition of animals varies depending on the type, feed, and environment of the animal originating.

\section{CONCLUSIONS}

The fleshing results that have been processed by deliming have $71.27 \%$ moisture content, $2.21 \%$ ash, $10.57 \%$ protein, $15.27 \%$ fat and $0.66 \%$ carbohydrate. Extraction using a combination of wet rendering and n-hexane on the by-product of fleshing produces relatively low fat/oil with water and ash content. The optimum yield $(11.10 \% \mathrm{w} / \mathrm{w})$ was obtained from the wet rendering treatment at $90{ }^{\circ} \mathrm{C}$ and extraction time of 2 hours. The treatment of temperature and extraction time in wet rendering followed by $n$-hexane affects the free fatty acid content, saponification number and peroxide number and color of fat/oil. The higher the temperature and the longer the wet rendering process results in fat with free fatty acid levels and higher saponification rates, but the lower the peroxide number, and the darker the color. The fatty acid component consists of 37 compounds which are a combination of saturated and unsaturated fatty acids. There are six fatty acids with a large/dominant presence, namely butyric acid methyl ester, tetradecanoic acid methyl ester, cis-10-pentadecenoid acid methyl ester, palmitoleic acid methyl ester, octadecanoic acid methyl ester, and trans9-elaidic acid methyl ester. This research can reduce pollution from fleshing by-products and process it into products that have added value.

\section{ACKNOWLEDGMENT}

The author would like to thank the Head of the Center for Leather, Rubber and Plastics (CLRP) Yogyakarta, which has provided an opportunity for author to conduct research.

\section{REFERENCES}

AOAC. (2005). Official methods of analysis of the association of analytical chemists international. 18th ed. Gathersburg: MD U.S.A Official methods.

Aziz, T., Cindo K. N., \& Asima, F. (2009). Pengaruh pelarut heksana dan etanol, volume pelarut, dan waktu ekstraksi terhadap hasil ekstraksi minyak kopi. Jurnal Teknik Kimia, 16(1), 1-8.

Cuq, M. H. B., Mlayah, B., \& Delmas, M. (1998). Oil extracted from seal hides: Characterization and use as leather fatliquor. Journal of the American Oil Chemists, Society, 75(8), 1015-1019. https://doi.org/10.1007/s11746-998-0280-8

Derlean,A. (2009). Pengaruh suhu dan lama pemanasan terhadap kerusakan minyak kelapa. Jurnal MIPA, Kependidikan dan Terapan, 1(1), 19-26.

Handayani, P. A., \& Juniarti, E. R. (2012). Ekstraksi minyak ketumbar (coriander oil) dengan pelarut etanol dan N-heksana. Jurnal Bahan Alam Terbarukan, 1(1), 1-7.

IUE-2. (2008). Recomendation for Tannery Solid by Product Management.

Kanagaraj, J., Velappan, K. C., Chandra Babu, N. K., \& Sadulla, S. (2006). Solid wastes generation in the leather industry and its utilization for cleaner environment - A review. Journal of Scientific and Industrial Research, 65(7), 541-48. https://doi.org/10.1002/chin.200649273

Karouw, S., \& Indrawanto, S. (2015). Perubahan mutu minyak kelapa dan minyak sawit selama penggorengan. Buletin Palma, 16(1), 1-7.

Ketaren. (1986). Pengantar teknologi minyak dan lemak pangan. UI-Press Jakarta.

Panagan, A. T., Yohandini, H., \& Gultom, J. U. (2011). Analisis kualitatif dan kuantitatif asam lemak tak jenuh omega-3 dari minyak ikan patin (Pangasius pangasius) dengan metoda kromatografi gas. Jurnal Penelitian Sains, 14(4), $38-42$.

Prayitno. (2017). Teknologi bersih proses penyamakan kulit. Yogyakarta: Grafika Indah.

Priebe, G. P. S., \& Gutterres, M. (2012). Olein production from pre-fleshing residues of hides in tanneries. Latin American Applied Research, 42, 71-76.

Rukmini, A., \& Raharjo, S. (2010). Pattern of peroxide value changes in virgin coconut oil (VCO) due to photooxidation sensitized by chlorophyll. Journal of the American Oil Chemists' Society, 87(12), 1407-1412. https://doi.org/10.1007/s11746-010-1641-7

Sahriawati, \& Daud. (2016). Optimasi proses ekstraksi minyak ikan metode soxhletasi dengan variasi jenis pelarut dan suhu berbeda. Jurnal Galung Tropika, 5(3), 164-70.

Siswanto, W., \& Mulasari, S. A. (2015). Pengaruh frekuensi penggorengan terhadap peningkatan peroksida minyak goreng curah dan fortifikasi vitamin A. Jurnal Kesmas, 9(1), 1-10.

Sopianti, D. S., Herlina, \& Saputra, H. T. (2017). Penetapan kadar asam lemak bebas pada minyak goreng. Jurnal Katalisator, 2(2), 100-105.

Supangat, I. (1976). Dasar-dasar kimia organik. Yogyakarta: Yayasan Penerbit FPMIPA-IKIP.

Susanti, C. M., Sugiharto, R., Setyani, R., \& Subekti. (2014). Pengaruh jumlah pelarut etanol dan suhu fraksinasi terhadap karakteristik lemak kakao hasil ekstraksi non alkalized cocoa powder. Jurnal Teknologi Industri Dan Hasil Pertanian, 19(2), 307-19. 
Sutyasmi, S., Sunaryo, I, \& Suraswati, A. (2006).

Teknologi pengambilan lemak dari sisa fleshing. Majalah Kulit, Karet, dan Plastik, 22(1), 32-37. https://doi.org/10.20543/mkkp.v22i1.333

Vogel. (1984). Textbook of practical organic chemistry. ELBS
Editi. Great Britain: William Clowes Elmited.

White, A., Handler, P ., \& Smith, E. L. (1964). Principles of biochemistry. Edited by Mc Grow-Hill Book. 3rded. New York, Toronto, London: Kogakusha Company LTD Tokyo. 
